\title{
Influence of Soybean Monoculture on Phialophora gregata f. sp. sojae IGS-Genotype B Isolate Aggressiveness
}

\author{
T. J. Hughes and C. R. Grau, Department of Plant Pathology, University of Wisconsin-Madison, Madison 53706
}

\begin{abstract}
Hughes, T. J., and Grau, C. R. 2010. Influence of soybean monoculture on Phialophora gregata f. sp. sojae IGS-genotype B isolate aggressiveness. Plant Dis. 94:69-74.

Many soybean accessions described as resistant to brown stem rot (BSR) are preferentially colonized by isolates of Phialophora gregata $\mathrm{f}$. sp. sojae genotype B. These isolates are generally considered less aggressive than isolates of $P$. gregata f. sp. sojae genotype A because they cause minor or no foliar symptoms characteristic of BSR. However, variation in aggressiveness has been observed among isolates of $P$. gregata $\mathrm{f}$. sp. sojae genotype B. To determine if BSRresistant soybean accessions would preferentially select for more aggressive isolates of $P$. gregata f. sp. sojae genotype B, monocultures of both BSR-resistant or BSR-susceptible accessions were established at the Arlington Agriculture Research Station, Arlington, WI. BSR-susceptible cv. Corsoy 79 and BSR-resistant plant introduction (PI) 567.157A were inoculated under greenhouse conditions with a total of 39 isolates of $P$. gregata f. sp. sojae genotype B obtained from the different monocultures. BSR severity was determined as the percentage of symptomatic foliar and internal stem tissue. Overall, BSR severity was low and did not exceed $20 \%$ for either foliar or stem symptoms. Isolates of $P$. gregata f. sp. sojae genotype B caused more severe foliar $(P<0.0001)$ and stem $(P=0.0008)$ symptoms of BSR on PI 567.157A than on Corsoy 79. Analysis of BSR stem symptom severity indicated an interaction $(P=0.0124)$ between soybean accession and the origin of isolates of $P$. gregata f. sp. sojae genotype B. Isolates of $P$. gregata $\mathrm{f}$. sp. sojae genotype B obtained from the monoculture of a BSR-susceptible or -resistant accession were more aggressive than isolates from a mixed resistant and susceptible soybean monoculture. The relationship between the origin of isolate of P. gregata f. sp. sojae genotype B and isolate aggressiveness was more apparent for PI 567.157A than for Corsoy 79. Results of this study indicate that the monoculture of resistant or susceptible soybean favors an increase in the aggressiveness of isolates of $P$. gregata f. sp. sojae genotype B. Furthermore, results suggest that resistance to genotype A may be genetically different from resistance to genotype B.
\end{abstract}

Brown stem rot (BSR) is a disease that continues to impact soybean (Glycine max) production in many areas of the northcentral United States (37). The symptoms associated with BSR include browning of the vascular and pith tissues (stem symptoms) and interveinal necrosis and chlorosis, wilting, and defoliation of the leaves (foliar symptoms). Although BSR can be successfully managed with crop rotation $(3,22)$ and soil tillage $(3,36)$, host resistance remains the preferred method of control (9). However, resistance to BSR in commercially available cultivars is limited to two main sources; cultivars containing one or more $R b s$ genes (9) or those derived from plant introduction (PI) 88788 (18,27). In addition to a narrow genetic base, the resistance in these cultivars has been defined as a reduction in symptom severity $(3,4,18)$ and not by the prevention or restriction of pathogen colonization $(7,20,24)$.

Corresponding author: T. J. Hughes

E-mail: tjh@plantpath.wisc.edu

Accepted for publication 3 September 2009.

doi:10.1094/PDIS-94-1-0069

(C) 2010 The American Phytopathological Society
The causal agent of BSR, Phialophora gregata f. sp. sojae (syn. Cadophora gregata; Cephalosporium gregatum), is a residue-borne fungal pathogen that survives between soybean crops as a saprophyte in host tissue colonized during its parasitic phase $(2,20)$. Isolates of $P$. gregata $\mathrm{f}$. sp. sojae can be classified as either genotype A or genotype B based on an insertion or deletion (INDEL) in the intergenic spacer region of ribosomal DNA (7). The two genotypes are common throughout the north-central United States and are often found in the same field. Genotypes A and B can infect both BSR-resistant and susceptible soybean cultivars as well as concurrently colonizing the same plant. However, data from several studies suggest that genotypes A and B exhibit cultivar preference $(7,17,24)$. Soybean cultivars classified as resistant are colonized at a greater frequency by isolates of genotype B than genotype A while cultivars classified as susceptible are colonized at a greater frequency by isolates of genotype A than genotype B. Among resistant cultivars, preferential colonization is further influenced by the source of resistance. Cultivars with resistance derived from PI 88788 are colonized significantly more by $P$. gregata $\mathrm{f}$. sp. sojae genotype $\mathrm{B}$ than resistant cultivars with one or more $R b s$ genes $(7,17,24)$.

Isolates of $P$. gregata f. sp. sojae genotypes $\mathrm{A}$ and $\mathrm{B}$ also differ in the type and severity of symptoms they produce $(12,16)$. Overall, isolates of $P$. gregata f. sp. sojae genotype A cause both BSR foliar and stem symptoms while isolates of genotype B cause stem discoloration and minor or no foliar symptoms. On BSRsusceptible cultivars, isolates of genotype A cause greater symptom severity than isolates of genotype B and are considered more aggressive $(12,16)$. However, variation in aggressiveness exists within populations of both genotypes. Isolates of genotype A range from benign to highly aggressive while isolates of genotype B range from benign to mildly aggressive $(12,15)$.

Prior to the identification of $P$. gregata f. sp. sojae genotypes, the monoculture of a BSR-resistant cultivar was believed to be as effective as crop rotation with a nonhost in decreasing disease incidence and severity (33). Although this conclusion was thought to be due to a decrease in inoculum quantity of $P$. gregata f. sp. sojae, current data suggest the decreases in disease incidence and severity may have been the result of a change in the genotypic structure of the $P$. gregata f. sp. sojae population in favor of genotype B $(16,17)$. Today, the interaction between soybean genotype and genotypes $\mathrm{A}$ and $\mathrm{B}$ of $P$. gregata $\mathrm{f}$. sp. sojae remains ambiguous. Because host resistance is the preferred method for controlling BSR, understanding the influence of soybean genotypes on $P$. gregata f. sp. sojae genotype B is necessary for the development and deployment of effective disease management strategies. To study the influence of host genotype on P. gregata f. sp. sojae genotype B, soybean accessions differing in resistance and susceptibility to BSR were monocultured from 2000 to 2005 with the goal of elucidating the interaction between $P$. gregata $\mathrm{f}$. sp. sojae and its soybean host. As part of this goal, the present study was developed to determine whether the continuous cropping of genetically different soybean accessions influenced aggressiveness, defined here as the amount of disease (symptom development), among isolates of P. gregata f. sp. sojae genotype B.

\section{MATERIALS AND METHODS}

In 2000, a field site was established at the Arlington Agricultural Research Sta- 
tion, Arlington WI, in an area with no history of soybean or P. gregata f. sp. sojae (17). Briefly, 10 soybean accessions were selected based on their genetic resistance or susceptibility to BSR (Table 1). Monocultures of each accession were established by planting each accession in the same 38 by- 9 m plot from 2000 through 2004 (Fig. 1). In 2005, plots were reduced in size to 3 by $9 \mathrm{~m}$, which allowed each accession to be planted in an area previously planted to itself as well as that of the nine other accessions (Fig. 1).

When soybean plants reached beginning maturity (R7), 15 plants were arbitrarily selected from within each plot, bulked into five groups of 3 plants each, and air dried at room temperature (2 to 3 days). For each bulk, approximately 13 to $15 \mathrm{~cm}$ of the lower stem was ground and dilution plated onto a semi-selective medium $(1,20)$. Plates were then placed in the dark at $12^{\circ} \mathrm{C}$ for 4 weeks. Following incubation, approximately 10 colonies of $P$. gregata $\mathrm{f}$. sp. sojae were arbitrarily selected from each plate and transferred onto quarterstrength potato dextrose agar (PDA) $(25 \mathrm{~g}$ of peeled, sliced potato tubers, $1.25 \mathrm{~g}$ of

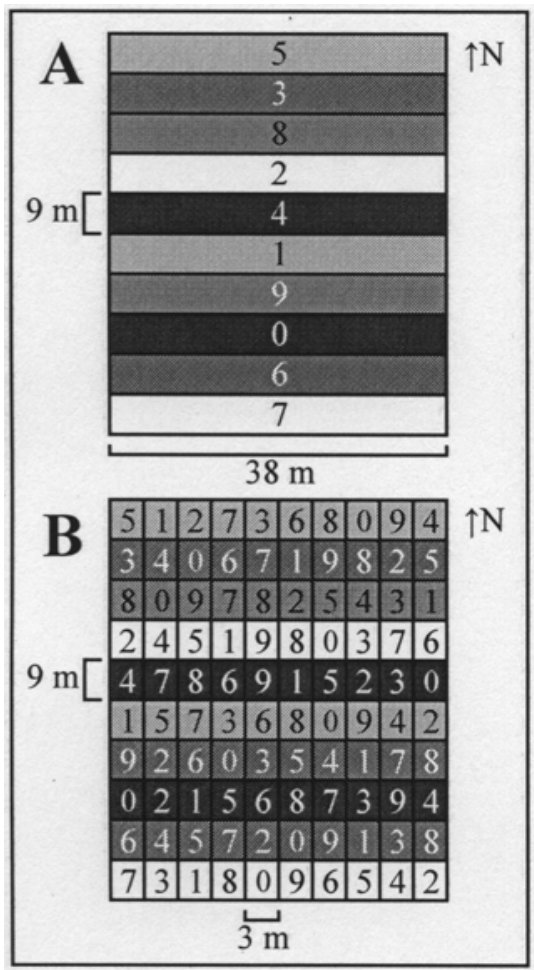

Fig. 1. Field design and layout for studying the influence of monocropping brown stem rot (BSR)-resistant (0-4) and BSR-susceptible (5-9) soybean accessions on stem and soil populations of Phialophora gregata f. sp. sojae. A, Field design from 2000 through 2004 in which accessions were planted continuously in the same location in each year. B, Field design for 2005 in which the direction of planting was rotated $90^{\circ}$ and the plot size reduced so that each accession was planted onto the monoculture of itself as well as that of the other nine accessions. Figure depicts one of four replications at Arlington, WI. dextrose, $7.5 \mathrm{~g}$ agar, and $500 \mathrm{ml}$ of deionized water). After 5 to 7 days of incubation at room temperature, one to five pureculture isolates were identified and transferred onto full-strength PDA. Following a subsequent 2-week incubation at room temperature, subcultures of each isolate were transferred to glass vials containing quarter-strength PDA and stored at $12^{\circ} \mathrm{C}$. The remaining mycelium was then used for DNA extraction and the genotype of each isolated determined by polymerase chain reaction (7). Of the 1,143 isolates of P. gregata f. sp. sojae obtained, $71 \%$ were identified as genotype B (17).

Isolates of $P$. gregata $\mathrm{f}$. sp. sojae genotype B were separated into four categories based on the cropping history of the plot from which the isolate was obtained (Fig. 2). Ten isolates were arbitrarily selected from within each of the four cropping histories and evaluated for aggressiveness based on BSR foliar and internal stem symptom severity (Fig. 2; Table 2). Spore suspensions of each isolate were prepared in 500-ml flasks containing $250 \mathrm{ml}$ of either green bean broth (40 $\mathrm{g}$ of Gerber 2nd Foods green bean baby food [Gerber, Freemont, MI] and $500 \mathrm{ml}$ of deionized water) or soybean seed broth ( $80 \mathrm{~g}$ of soybean seed, cv. Bell, and 1 liter of deionized water). Flasks were inoculated with three plugs of mycelium from an actively growing culture on PDA and incubated at room temperature on a rotary shaker for approximately 2 weeks. Following incubation, green bean and soybean seed broth cultures were combined and blended in 1liter beakers with a Braun (Boston) vertical hand mixer and the concentration of conidia and mycelial fragments determined with a hemacytometer. Inoculum was adjusted to $1 \times 10^{6}$ conidia and mycelium per milliliter with de-ionized water and stored at $-20^{\circ} \mathrm{C}$ until inoculation.

Seed of BSR-susceptible soybean cv. Corsoy 79 (24) and BSR-resistant PI 567157A (21) were germinated in mediumgrade vermiculite in $25.4-\mathrm{by}-50.8-\mathrm{cm}, 96-$ well flats containing commercial-grade

Table 1. Soybean accessions grown from 2000 through 2005 at Arlington, WI

\begin{tabular}{lccc}
\hline Soybean accession & $\begin{array}{c}\text { BSR } \\
\text { reaction }^{\mathbf{a}}\end{array}$ & BSR-R source or gene $^{\mathbf{b}}$ & $\begin{array}{c}\text { BSR-S soybean accession } \\
\text { in parentage }\end{array}$ \\
\hline BSR 101 & $\mathrm{R}$ & $R b s 1,3$ & $\ldots$ \\
IA 2008R & $\mathrm{R}$ & $R b s 1,3$ & $\ldots$ \\
LN92-120334 & $\mathrm{R}$ & $R b s 2$ & $\ldots$ \\
Dwight & $\mathrm{R}$ & $\mathrm{PI} 88788$ & $\ldots$ \\
Jack & $\mathrm{R}$ & $\mathrm{PI} 88788$ & $\ldots$ \\
Sturdy & $\mathrm{S}$ & $\ldots$ & Century \\
Corsoy 79 & $\mathrm{S}$ & $\ldots$ & Corsoy \\
Hardin & $\mathrm{S}$ & $\ldots$ & Corsoy \\
Pioneer 9234 & $\mathrm{~S}$ & $\ldots$ & Peking \\
Williams 82 & $\mathrm{~S}$ & $\ldots$ & Peking \\
\hline
\end{tabular}

a Reaction of soybean accession to brown stem rot (BSR); $\mathrm{R}=$ resistant and $\mathrm{S}=$ susceptible.

${ }^{\mathrm{b}}$ Gene or genes conferring resistance or source (plant introduction [PI]) used to obtain resistance to BSR.

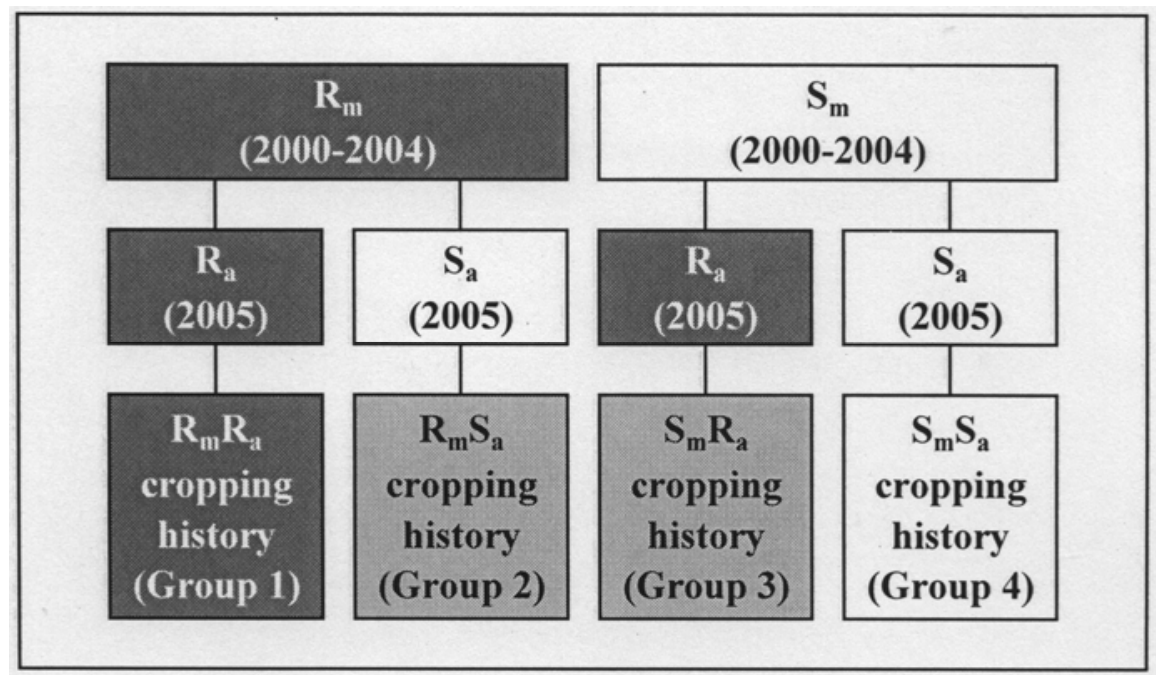

Fig. 2. Diagrammatic representation of the four soybean cropping histories from which isolates of Phialophora gregata f. sp. sojae genotype $\mathrm{B}$ were obtained. $\mathrm{R}_{\mathrm{m}}=$ brown stem rot (BSR)-resistant accession monocultured from 2000 through 2004. $\mathrm{S}_{\mathrm{m}}=\mathrm{BSR}$-susceptible accession monocultured from 2000 through 2004. $\mathrm{R}_{\mathrm{a}}=\mathrm{BSR}$-resistant accession planted in 2005 from which the isolate of . gregata f. sp. sojae genotype B was obtained. $\mathrm{S}_{\mathrm{a}}=\mathrm{BSR}$-susceptible accession planted in 2005 from which the isolate of $P$. gregata f. sp. sojae genotype B was obtained. 
Bradyrhizobium japonicum (Nitragin Inoculants, Liphatech Inc., Milwaukee, WI). Seedlings were inoculated approximately 14 days after seeding, at the VC-V1 growth stage (unifoliate leaves fully expanded), using a modified root-dip method as previously described (16). Briefly, nine seedlings of each cultivar were removed from vermiculite and the roots were rinsed in water. Roots were trimmed so that approximately 3 to $4 \mathrm{~cm}$ of root remained, and the seedlings were placed into a 250$\mathrm{ml}$ beaker containing inoculum of a single isolate for $20 \mathrm{~min}$. The method was repeated for each isolate, including two isolates of $P$. gregata f. sp. sojae genotype A (Table 2) (16), which were included as a positive control. Negative control plants were mock inoculated in the same method by using a sterilized, quarter-strength mixture of green bean and soybean seed broths.

Immediately following inoculation, seedlings were transplanted to $15.2-\mathrm{cm}$ fiber pots (Formart Containers, Inc., Cedarburg, WI) containing a 1:1 mixture of Sun Gro (Bellevue, WA) Metro Mix-300 and Pro-Moss-TBK (Quakertown, PA) sphagnum peat moss. Each cultivar-isolate combination was replicated three times, with three plants per pot, and arranged in a completely randomized blocked design (RCBD). Plants were fertilized once a week with Peter's 20-10-20 peat-lite special and treated as needed with Safer brand (Safer, Inc., Woodstream Corp., Lititz, PA) sulfur spray or $1.6 \%$ ultrapure oil (Whitmire Micro-Gen Research Laboratories, Inc., St. Louis) plus 0.1\% Latron B-1956 spreader-sticker (Dow Agrosciences, LLC., Indianapolis, IN) for control of powdery mildew. Plants were grown for approximately 6 to 7 weeks until the R2 to R3 growth stage (full flowering to beginning pod). Each plant per pot was then rated for BSR foliar and internal stem symptom severity by visually estimating the percentage of tissue symptomatic of BSR and assigning a Horsfall-Barratt (HB) rating (19). This study was conducted three times (three experimental runs), consecutively, from 16 October 2008 to 11 June 2008 at the West Madison Agricultural Research Station Greenhouses, Madison, WI. Greenhouses were programmed with a 14$\mathrm{h}$ photoperiod supplemented by metal halide and high-pressure sodium lamps, with average daytime and nighttime temperatures at 26 and $18^{\circ} \mathrm{C}$, respectively.

All ratings based on $\mathrm{HB}$ values were converted to percentages prior to analysis by using the Elanco conversion tables (30). Disease severity values for each of the three plants per pot were averaged and the means analyzed as an RCBD by using PROC MIXED (SAS version 9.1; SAS Institute, Cary, NC). Isolate of $P$. gregata $\mathrm{f}$. sp. sojae genotype $\mathrm{B}$, experimental run, and the interaction of experimental runblock were treated as random effects. Least significant difference comparisons of the means were made by using the LSMEANS and PDIFF options. Comparisons of the mean were conducted at $P<0.05$. Contrast statements were used for individual mean comparisons. Model assumptions were examined with PROC UNIVARIATE and studentized residuals prior to analysis.

\section{RESULTS}

Symptom development in BSRsusceptible cv. Corsoy 79 inoculated with $P$. gregata f. sp. sojae genotype A suggest that greenhouse environmental conditions were conducive for disease development during all three experimental runs (Table 3). However, foliar symptom severity was noticeably lower for Corsoy 79 in the third experimental run, which was likely the result of higher than average greenhouse temperatures during May and June (9). In spite of this, BSR foliar and internal stem symptom severity was lower for BSRresistant PI 567.157A than for susceptible Corsoy 79 in each experimental run when inoculated with $P$. gregata $\mathrm{f}$. $\mathrm{sp}$. sojae genotype A (Table 3 ).

As expected $(12,16)$, both foliar and internal stem symptom severity was low $(<20 \%)$ on Corsoy 79 and PI 567.157A inoculated with $P$. gregata f. sp. sojae genotype B for all three experimental runs. Similar to the results observed for inoculation with genotype A, foliar symptom severity was visibly reduced in the third experimental run for both Corsoy 79 and PI 567.157A inoculated with isolates of genotype B (data not shown). Regardless

Table 2. Designation and origin of isolates of Phialophora gregata f. sp. sojae

\begin{tabular}{|c|c|c|c|c|}
\hline \multirow[b]{2}{*}{ Isolate } & \multirow[b]{2}{*}{ Genotype $^{\mathrm{a}}$} & \multicolumn{2}{|c|}{ Soybean accession } & \multirow[b]{2}{*}{ Cropping history $^{\mathrm{d}}$} \\
\hline & & $\begin{array}{l}\text { Monoculture } \\
(2000-2004)^{b}\end{array}$ & $\begin{array}{c}\text { Sampled accession } \\
(2005)^{\mathrm{c}}\end{array}$ & \\
\hline 1014-5A & B & Dwight & LN92-12033 & $\mathrm{R}-\mathrm{R}$ \\
\hline $1019-3$ & B & Dwight & Jack & $\mathrm{R}-\mathrm{R}$ \\
\hline $1026-1$ & B & Jack & Jack & $\mathrm{R}-\mathrm{R}$ \\
\hline 2010-4 & B & LN92-12033 & IA $2008 \mathrm{R}$ & $\mathrm{R}-\mathrm{R}$ \\
\hline $2082-5$ & B & BSR 101 & BSR 101 & $\mathrm{R}-\mathrm{R}$ \\
\hline $3037-3$ & B & LN92-12033 & BSR 101 & $\mathrm{R}-\mathrm{R}$ \\
\hline $3047-2$ & B & Jack & Jack & $\mathrm{R}-\mathrm{R}$ \\
\hline 3078-1B & B & Dwight & Jack & $\mathrm{R}-\mathrm{R}$ \\
\hline 4023-1 & B & IA $2008 \mathrm{R}$ & Jack & $\mathrm{R}-\mathrm{R}$ \\
\hline $4079-4$ & B & LN92-12033 & LN92-12033 & $\mathrm{R}-\mathrm{R}$ \\
\hline $1017-2 \mathrm{~A}$ & B & Dwight & Pioneer 9234 & R-S \\
\hline 1021-5B & B & Jack & Hardin & R-S \\
\hline $1023-5$ & B & Jack & Pioneer 9234 & R-S \\
\hline $2060-2$ & B & Jack & Pioneer 9234 & R-S \\
\hline $3095-3$ & B & BSR 101 & Williams 82 & R-S \\
\hline $4006-2$ & B & Dwight & Hardin & R-S \\
\hline $4009-1$ & B & Dwight & Pioneer 9234 & R-S \\
\hline $4075-2$ & B & LN92-12033 & Hardin & R-S \\
\hline $4081-5$ & B & Jack & Sturdy & R-S \\
\hline $1031-1 \mathrm{~A}$ & B & Williams 82 & IA $2008 \mathrm{R}$ & S-R \\
\hline $1035-1$ & B & Williams 82 & Jack & S-R \\
\hline $1040-4 \mathrm{~A}$ & B & Williams 82 & BSR 101 & S-R \\
\hline $2078-5$ & B & Sturdy & Jack & S-R \\
\hline 2091-5B & B & Williams 82 & BSR 101 & S-R \\
\hline $3027-4$ & B & Pioneer 9234 & IA 2008R & S-R \\
\hline $3081-3$ & B & Corsoy 79 & LN92-12033 & S-R \\
\hline $4019-2$ & B & Hardin & Jack & S-R \\
\hline $4019-2$ & B & Hardin & Jack & S-R \\
\hline $4033-5$ & B & Corsoy 79 & Jack & S-R \\
\hline $1033-1 \mathrm{C}$ & B & Williams 82 & Sturdy & S-S \\
\hline $1037-3$ & B & Williams 82 & Corsoy 79 & S-S \\
\hline 2043-1 & B & Corsoy 79 & Corsoy 79 & S-S \\
\hline 2075-5B & B & Sturdy & Pioneer 9234 & S-S \\
\hline $2076-5$ & B & Sturdy & Williams 82 & S-S \\
\hline 2098-1(1) & B & Williams 82 & Corsoy 79 & S-S \\
\hline $3025-3 \mathrm{~A}$ & B & Pioneer 9234 & Hardin & S-S \\
\hline $3063-5$ & B & Hardin & Sturdy & S-S \\
\hline $4049-2$ & B & Williams 82 & Williams 82 & S-S \\
\hline $4065-2$ & B & Sturdy & LN92-12033 & S-R \\
\hline $4098-5$ & B & Pioneer 9234 & Pioneer 9234 & S-S \\
\hline $3051-2$ & A & IA 2008R & Corsoy 79 & $\mathrm{R}-\mathrm{S}$ \\
\hline Fulton- $-\mathrm{OH}^{\mathrm{e}}$ & A & Unknown & Unknown & Unknown \\
\hline
\end{tabular}

${ }^{a}$ Genotype of $P$. gregata f. sp. sojae isolate determined by polymerase chain reaction (7).

${ }^{\mathrm{b}}$ Soybean accession grown in the same location for 5 years.

${ }^{c}$ Soybean accession planted in 2005 from which the isolate of $P$. gregata f. sp. sojae was obtained.

${ }^{\mathrm{d}}$ Reaction of soybean accession to brown stem rot (BSR) grown in the same location for 5 years (first letter) followed by the reactions of the soybean accession to BSR planted in 2005 from which the isolate of $P$. gregata f. sp. sojae was obtained (second letter). $\mathrm{R}=$ resistant and $\mathrm{S}=$ susceptible.

${ }^{\text {e }}$ Standard, aggressive isolate of $P$. gregata f. sp. sojae genotype A $(7,15,16)$. 
of the differences in symptom severity obtained across the three experimental runs, preliminary analysis did not indicate an effect of experimental run on either foliar or stem symptom severity. Therefore, data from all three experimental runs was combined for analysis.

BSR-resistant PI 567.157A expressed greater $(P<0.0001)$ foliar and stem $(P<$ 0.0008 ) symptom severity than susceptible Corsoy 79 when inoculated with isolates of P. gregata f. sp. sojae genotype B (Fig. 3). Analysis of BSR stem symptom severity revealed an interaction $(P=0.0124)$ between soybean accession and the origin of isolates of genotype B. Isolates of genotype B obtained from the monoculture of a BSR-resistant or -susceptible accession caused greater $(P=0.0020)$ stem symptom severity on BSR-resistant PI 567.157A than isolates obtained from a mixed resistant and susceptible soybean monoculture (Fig. 4). On BSR-susceptible cv. Corsoy 79 , isolates of genotype B obtained from the monoculture of a BSR-susceptible accession caused greater $(P=0.0573)$ stem symptom severity than isolates obtained from a mixed soybean monoculture or the monoculture of a BSR-resistant accession (Fig. 4). As with the results observed on PI 567.157A, isolates of genotype B obtained from the monoculture of a BSR-resistant accession tended to cause greater stem symptom severity on Corsoy 79 than isolates from a mixed soybean monoculture; however, this difference was not significant. Analysis of BSR foliar symptoms showed no relationship between the origin of isolates of genotype B and BSR foliar symptom severity (Fig. 4).

Analysis of foliar and stem symptom severity did not indicate a relationship between the different sources of BSR resistance and isolate aggressiveness. Isolates of $P$. gregata $\mathrm{f}$. sp. sojae genotype B obtained from a PI 88788-derived BSRresistant monoculture did not differ in aggressiveness (foliar: $P=0.579$; stem: $P$ $=0.909$ ) from those isolates obtained from an $R b s$-derived BSR-resistant monoculture. In addition, no differences in aggressiveness were observed for isolates of genotype B obtained from a PI 88788/Rbs-

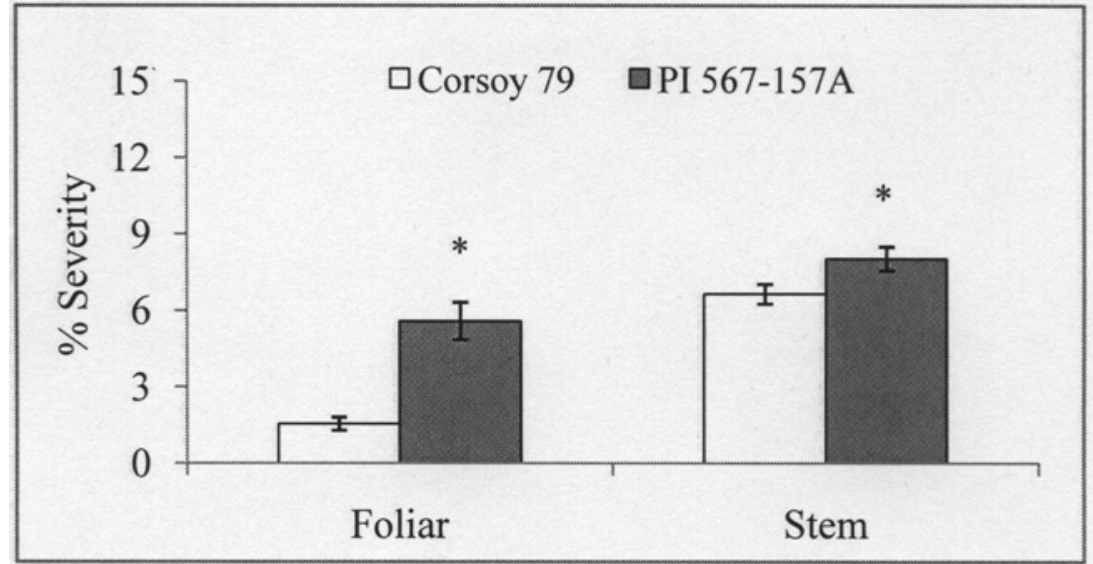

Fig. 3. Brown stem rot (BSR) foliar and stem symptom severity for BSR-susceptible cv. Corsoy 79 and BSR-resistant plant introduction (PI) 567.157A inoculated with 39 isolates of Phialophora gregata f. sp. sojae genotype B. Symptom severity was assessed by visually estimating the percentage of symptomatic tissue and assigning a Horsfall-Barratt (HB) rating. HB ratings were converted to percentages prior to analysis. Values are the means of three experimental replications. Bars represent one standard error of the mean. Means marked by an asterisk $(*)$ are significantly different at $P=0.05$.

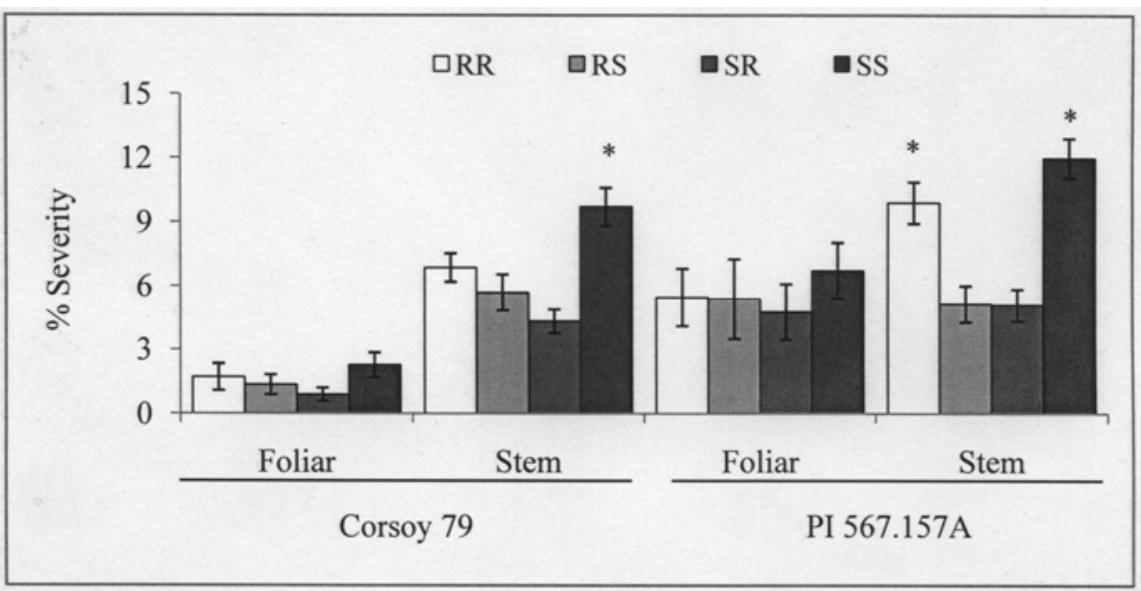

Fig. 4. Brown stem rot (BSR) foliar and stem symptom severity for BSR-susceptible cv. Corsoy 79 and BSR-resistant plant introduction (PI) 567.157A inoculated with 39 isolates of Phialophora gregata f. sp. sojae genotype B obtained from one of four soybean cropping histories (9-10 isolates per cropping history). RR = BSR-resistant accession monocultured from 2000 through 2004 followed by the planting of a BSR-resistant accession in 2005 from which the isolate of genotype B was obtained. RS = BSR-resistant accession monocultured from 2000 through 2004 followed by the planting of a BSRsusceptible accession in 2005 from which the isolate of genotype B was obtained. SR = BSRsusceptible accession monocultured from 2000 through 2004 followed by the planting of a BSRresistant accession in 2005 from which the isolate of genotype B was obtained. SS = BSR-susceptible accession monocultured from 2000 through 2004 followed by the planting of a BSR-susceptible accession in 2005 from which the isolate of genotype B was obtained. Symptom severity was assessed by visually estimating the percentage of symptomatic tissue and assigning a Horsfall-Barratt (HB) rating. HB ratings were converted to percentages prior to analysis. Bars represent one standard error of the mean. Means marked by an asterisk (*) are significantly different at $P=0.05$.

Table 3. Percent foliar and internal stem symptoms characteristic of brown stem rot (BSR) for BSR-susceptible cv. Corsoy 79 and BSR-resistant plant introduction (PI) 567.157A inoculated with isolates of Phialophora gregata f. sp. sojae genotype A

\begin{tabular}{|c|c|c|c|c|c|c|}
\hline \multirow[b]{3}{*}{ Accession } & \multicolumn{6}{|c|}{ Symptom severity ${ }^{\mathrm{a}}$} \\
\hline & \multicolumn{2}{|c|}{ Experimental run 1} & \multicolumn{2}{|c|}{ Experimental run 2} & \multicolumn{2}{|c|}{ Experimental run 3} \\
\hline & Foliar & Stem & Foliar & Stem & Foliar & Stem \\
\hline Corsoy 79 & $81.1^{ \pm 4.7}$ & $25.5^{ \pm 7.7}$ & $93.2^{ \pm 0.8}$ & $42.9^{ \pm 7.3}$ & $33.7^{ \pm 14.7}$ & $21.9^{ \pm 7.0}$ \\
\hline PI 567.157A & $48.1^{ \pm 12.6}$ & $13.9^{ \pm 5.3}$ & $2.4^{ \pm 1.8}$ & $14.3^{ \pm 3.0}$ & $0^{ \pm 0.0}$ & $6.5^{ \pm 1.6}$ \\
\hline $\mathrm{LSD}^{\mathrm{b}}$ & 30.9 & & 4.6 & 15.8 & 33.9 & 16.3 \\
\hline$P$ value & 0.043 & 0.15 & $<0.0001$ & 0.003 & 0.051 & 0.061 \\
\hline
\end{tabular}

${ }^{a}$ Mean percent tissue symptomatic of BSR for three replications per experimental run. Symptom severity was assessed by visually estimating the percentage of symptomatic tissue and assigning a Horsfall-Barratt (HB) rating. HB ratings were converted to percentages and the values for plants inoculated with each isolate of $P$. gregata f. sp. sojae genotype A combined prior to analysis; \pm represents one standard error of the mean. Study was conducted three times, consecutively, from 16 October 2008 to 11 June 2008.

${ }^{b} \mathrm{LSD}=$ least significant difference at $P=0.05$. 
resistant monoculture. Similar results were observed with isolates of genotype B obtained from BSR-susceptible soybean monocultures or a culture of different susceptible soybean accessions.

\section{DISCUSSION}

The long-term monoculture of a single agronomic crop coincides with an increase in the incidence and severity of many plant diseases. This increase has been associated with either a build-up of inoculum or an increase in pathogen aggressiveness $(13,28)$. In previous studies with various fungal pathogens $(6,8,13,14)$, results indicate an increase in isolate aggressiveness when resistant or susceptible cultivars are monocultured over time. Similarly, the results of this study indicate that the monoculture of soybean accessions resistant or susceptible to BSR influences the aggressiveness of isolates of $P$. gregata $\mathrm{f}$. sp. sojae genotype B.

The more aggressive isolates of $P$. gregata f. sp. sojae genotype B were obtained from the monoculture of BSR-susceptible soybean accessions followed by those isolates obtained from the monoculture of BSR-resistant accessions. Although soybean was in continuous cultivation, monocultures in which both resistant and susceptible soybean accessions were grown yielded the least aggressive isolates of $P$. gregata f. sp. sojae genotype $\mathrm{B}$. The increased aggressiveness of isolates of genotype B obtained from areas continuously cropped to purely resistant or susceptible soybean accessions compared with those obtained from a mixed soybean monoculture may be indicative of a negative feedback. In ecological studies $(25,29,35)$, negative feedbacks are hypothesized to be a way that native systems maintain diversity in plant communities. When a single plant species occupies an area, changes are thought to take place in the soil community that decreases the growth of that species relative to another. As such, plants of one species may cause the build-up of pathogenic soilborne microorganisms that reduce the succession success of the same species. In the present study, although a single plant species was used, differences in the genetics between BSR-resistant and -susceptible accessions may be sufficient to initiate a negative feedback.

Today, economic considerations may triumph over sound agronomic practices as more soybean growers consider continuous soybean production. In production systems where crop rotations are limited or nonexistent, disease management strategies may include rotating cultivars with different sources of resistance to mitigate increases in disease incidence and severity $(31,34,38)$. Resistance to BSR in commercially available cultivars is limited to those containing one or more $R b s$ genes (9) or cultivars derived from PI $88788(18,27)$. Although, genetically, these sources map to the same region of the soybean genome (27), studies have shown that both disease development and pathogen interactions differ between cultivars derived from PI 88788 and those containing an $R b s$ gene $(17,18,24)$. However, from the results of this study, both sources of BSR resistance favored isolates of $P$. gregata $\mathrm{f}$. sp. sojae genotype $B$ with similar aggressiveness. Therefore, in continuous soybean production systems, rotating cultivars with different sources of BSR resistance may not be a practical option for managing BSR.

As expected $(12,16)$, symptom severity was generally low $(<20 \%)$ for both BSRsusceptible Corsoy 79 and BSR-resistant PI 567.157A inoculated with isolates of $P$. gregata f. sp. sojae genotype B. However, PI 567.157A expressed more severe foliar and stem symptoms than Corsoy 79. Screening for resistance to BSR typically uses isolates of $P$. gregata f. sp. sojae that are described as "aggressive", "defoliating", or "Type 1" (10), suggesting that isolates are of the A genotype $(11,18,26)$. In addition, numerous studies use isolate $\mathrm{Oh} 2$, an isolate of $P$. gregata $\mathrm{f}$. sp. sojae genotype A that has been in continuous culture since the 1970s $(4,5,23,27,32)$. Consequently, little is known about resistance to $P$. gregata f. sp. sojae genotype B. The increase in foliar and stem symptoms severity observed for PI 567.157A compared with Corsoy 79 when inoculated with genotype B suggests that (i) resistance has been identified to genotype A but not to genotype $\mathrm{B}$ and (ii) resistance to genotype A may be genetically different from resistance to genotype B. Results of this study indicate the need to include isolates of both genotypes in resistance breeding and to consider soybean genetics as well as reaction to BSR when making cultivar selection.

\section{LITERATURE CITED}

1. Adee, E. A., Grau, C. R., and Oplinger, E. S. 1995. Inoculum density of Phialophora gregata related to severity of brown stem rot and yield of soybean in microplots studies. Plant Dis. 79:68-73.

2. Adee, E. A., Grau, C. R., and Oplinger, E. S. 1997. Population dynamics of Phialophora gregata in soybean residue. Plant Dis. 81:199203.

3. Adee, E. A., Oplinger, E. S., and Grau, C. R. 1994. Tillage, rotation sequence, and cultivar influences on brown stem rot and soybean yield. J. Prod. Agric. 7:341-347

4. Bachman, M. S., and Nickell, C. D. 2000. High frequency of brown stem rot resistance in soybean germ plasm from central and southern China. Plant Dis. 84:694-699.

5. Bachman, M. S., Nickell, C. D., Stephens, P. A., and Nickell, A. D. 1997. Brown stem rot resistance in soybean germ plasm from central China. Plant Dis. 81:694-699.

6. Black, M. C., Beute, M. K., and Leonard, K. J. 1984. Effects of monoculture with susceptible and resistant peanuts on the virulence of $\mathrm{Cyl}$ indrocladium crotalariae. Phytopathology 74:945-950.

7. Chen, W., Grau, C. R., Adee, E. A., and Meng, X. -Q. 2000. Molecular marker identifying subspecific populations of the soybean brown stem rot pathogen, Phialophora gregata. Phytopathology 90:875-883.

8. Cowger, C., and Mundt, C. 2002. Aggressiveness of Mycosphaerella graminicola isolates from susceptible and partially resistant wheat cultivars. Phytopathology 92:624-630.

9. Grau, C. R., Dorrance, A. E., Bond, J., and Russin, J. S. 2004. Fungal diseases. Pages 679763 in: Soybeans: Improvement, Production, and Uses, 3rd ed. H. R. Boerma and J. E. Specht, eds. American Society of Agronomy, Inc., Crop Science Society of America, Inc., and Soil Science Society of America, Inc. Madison, WI.

10. Gray, L. E. 1971. Variation in pathogenicity of Cephalosporium gregatum isolates. Phytopathology 61:1410-1411.

11. Hanson, P. M., Nickell, C. D., Gray, L. E., and Sebastian, S. A. 1988. Identification of two dominant genes conditioning brown stem rot resistance in soybean. Crop Sci. 28:41-43.

12. Harrington, T. C., Steimel, J., Workneh, F., and Yang, X. B. 2003. Characterization and distribution of two races of Phialophora gregata in the North Central United States. Phytopathology 93:901-912.

13. Holguin, G., and Bashan, Y. 1992. Increased aggressiveness of Alternaria macrospora, a causal agent of leaf blight in cotton monoculture. Can. J. Bot. 70:1878-1884.

14. Hopkings, D. L., Lobinske, R. J., and Larkin, R. P. 1992. Selection for Fusarium oxysporum f. sp. niveum race 2 in monocultures of watermelon cultivars resistant to Fusarium wilt. Phytopathology 82:290-293.

15. Hughes, T. J. 2001. Pathogenic characterization of genotypes A and B of Phialophora gregata f. sp. sojae. Pages 64-89 in: Master's thesis, chapter 2, University of WisconsinMadison, Madison.

16. Hughes, T. J., Chen, W., and Grau, C. R. 2002. Pathogenic characterization of genotypes A and B of Phialophora gregata f. sp. sojae. Plant Dis. 86:729-735.

17. Hughes, T. J., Koval, N. C., Esker, P. D., and Grau, C. R. 2009. Influence of monocropping brown stem rot-resistant and susceptible soybean accessions on soil and stem populations of Phialophora gregata f. sp. sojae. Plant Dis. 93:1050-1058.

18. Hughes, T. J., Kurtzweil, N. C., Diers, B. W., and Grau, C. R. 2004. Resistance to brown stem rot in soybean germ plasm with resistance to the soybean cyst nematode. Plant Dis. 88:761-768.

19. Horsfall, J. G., and Barratt, R. W. 1945. An improved grading system for measuring plant disease. (Abstr.) Phytopathology 35:655.

20. Impullitti, A. E., and Grau, C. R. 2006. Population dynamics of Phialophora gregata in stem residue of a resistant and a susceptible soybean cultivar. Plant Dis. 90:759-764.

21. Impullitti, A. E., Malvick, D. K., and Grau, C. R. 2009. Characterizing reaction of soybean to Phialophora gregata using pathogen population density and DNA quantity in stems. Plant Dis. 93:734-740.

22. Kennedy, B. W., and Lambert, J. W. 1981 Influences of brown stem rot and cropping history on soybean performance. Plant Dis. 65:896-897.

23. Lewers, K. S., Crain, E. H., Bronson, C. R., Schupp, J. M., Keim, P., and Shoemaker, R. C. 1999. Detection of linked QTL for soybean brown stem rot resistance in "BSR 101" as expressed in a growth chamber environment. Mol. Breed.5:33-42.

24. Malvick, D. K., Chen, W., Kurle, J. E., and Grau, C. R. 2003. Cultivar preference and genotype distribution of the brown stem rot pathogen Phialophora gregata in the Midwestern United States. Plant Dis. 87:1250 1254.

25. Mills, K. E., and Bever, J. D. 1989. Mainte- 
nance of diversity within plant communities: soil pathogens as agents of negative feedback. Ecology 79:1595-1601.

26. Nelson, R. L., Nickell, C. D., Orf, J. H., Tachibana, H., Gritton, E. T., Grau, C. R., and Kennedy, B. W. 1989. Evaluation soybean germ plasm for brown stem rot resistance. Plant Dis. 73:110-114.

27. Patzoldt, M. E., Grau, C. R., Stephens, P. A., Kurtzweil, N. C., Carlson, S. R., and Diers, B. W. 2005. Localization of a quantitative trait locus providing brown stem rot resistance in the soybean cultivar Bell. Crop Sci. 45:1241-1248.

28. Persson, L., Larsson-Wikström, M., and Gerhardson, B. 1999. Assessment of soil suppressiveness to Aphanomyces root rot of pea. Plant Dis. 83:1108-1112.

29. Petermann, J. S., Fergus, A. J. F., Turnbull, L. A., and Schmid, B. 2008. Janzen-Connell effects are widespread and strong enough to maintain diversity in grasslands. Ecology
89:2399-2406.

30. Redman, C. E., King, E. P., and Brown, J. F., Jr. 1969. Elanco Conversion Tables for BarrattHorsfall Rating Numbers. Eli Lilly and Co. Research Labs. Indianapolis, IN.

31. Sullivan, M. J., Melton, T. A., and Shew, H. D. 2005. Managing the race structure of Phytophthora parasitica var. nicotianae with cultivar rotation. Plant Dis. 89:1285-1294.

32. Tabor, G. M., Cianzio, S. R., Tylka, G. L., Roorda, R., and Bronson, C. R. 2006. A new greenhouse method to assay soybean resistance to brown stem rot. Plant Dis. 90:11861194.

33. Tachinbana, H., Epstein, A. H., and Havlovic, B. J. 1989. Effect of four years of continuous cropping of maturity group II soybeans resistant to brown stem rot on brown stem rot and yield. Plant Dis. 73:846-849.

34. Turkington, T. K., Xi, K., Tewari, J. P., Lee, H. K., Clayton, G. W., and Harker, K. N. 2005.
Cultivar rotation as a strategy to reduce leaf diseases under barley monoculture. Can. J. Plant Pathol. 27:283-290.

35. Van der Putten, W. H., Van Dijk, C., and Peters, B. A. M. 1993. Plant-specific soil-borne diseases contribute to succession in foredune vegetation. Nature 362:53-56.

36. Workneh, F., Yang, X. B., and Tylka, G. L. 1999. Soybean brown stem rot, Phytophthora sojae, and Heterodera glycines affected by soil texture and tillage relations. Phytopathology 89:844-850.

37. Wrather, J. A., and Koenning, S. R. 2006 Estimates of disease effects on soybean yields in the United States 2003 to 2005. J. Nematol. 38:173-180.

38. Zhan, J., Fitt, B. D. L., Pinnschmidt, H. O., Oxley, S. J. P., and Newton, A. C. 2008. Resistance, epidemiology and sustainable management of Rhynchosporium secalis populations on barley. Plant Pathol. 57:1-14. 